\title{
RELIGIOUS VALUES IN THE THEME STRUCTURE OF TRADITIONAL SELOKO OF JAMBI MALAY
}

\author{
Ade Rahima ${ }^{1}$, Sakura Ridwan ${ }^{2}$ \\ ${ }^{1}$ Batanghari University, Jambi, Indonesia \\ ${ }^{2}$ Universitas Negeri Jakarta, Indonesia \\ 1ade_rahima@yahoo.com
}

\begin{abstract}
The objective of this research is to get a deep understanding about religious values in the theme structure of traditional Seloko of Jambi Malay. This research used content analysis method to analyze the extrinsic elements of seloko containing religious values. This method was combined with hermeneutic study technique to reveal the structure and implicit meanings of the texts in Jambi Malay seloko. Data in this research are traditionalseloko containing religious values. Primary data were obtained from a collection of traditional seloko of Jambi Malay recorded by Lembaga Adat of Jambi Province. The results of this research show that the themes of traditional seloko of Jambi Malay are related to the religious values of man's relationship with God, man with nature, man with society, and man with himself.
\end{abstract}

Keywords: religious values; traditional seloko; Jambi Malay.

Jambi Malay's traditional Seloko is a traditional expression that contains the rules of law that characterizes the culture of Jambi society. As a traditional expression, Seloko of Jambi Malay is part of the oral tradition passed down from generation to generation in the form of speeches and expressions. The symbolic meaning contained in the structure of traditional Seloko theme comprises message, mandate, or advice that is laden with religious values.

The use of the Seloko expression is a habit of daily Jambi community as the affirmation of values and norms. From the variety of Selokoexpression, the customary role of Jambi custom in fostering community Jambi as well as the sanctions for any a violation of customary law may be traced (Sagimun, 1985: 183). Expressions of Seloko of Jambi Malay Custom is a codification of values that reflect the lives of the people Jambi which are characterized by religious values. Religious values in social life of the Jambi Malay is is reflected in traditional Seloko expression which reads:Adat bersendi Syarak, Syarak bersendi Kitabullah (Syam,2002:18). The effort to formulate religious values through expressions of traditional Seloko is a symbolic activities undertaken by the Jambi people. The symbols are loaded with philosophical meaning contained in the traditional Seloko to express religious values. According to Cassirer (1979: 315), this shows men are involved in a tangle of symbols expressed through myth, religion, customs, language, art, history, and science.

This study aims to get a comprehensive understanding of religious values in the structure of traditional Seloko theme of Jambi Malay. After understanding such religious values, it is expected that appreciation to the old literature mainly oral literature of traditional Seloko which is a reflection of the religious behavior of Jambi Malay society may be nurtured. After the appreciation is nurtured, it is expected that consciousness to explore and implement religious values that exist in traditional 
Seloko of Jambi Malay will be grown and explored and it can be passed over to younger generations for the purpose of future life.In addition, this paper aims to inform the reader, researcher and observer of literature that religious values contained in traditional Seloko of Jambi Malay are noble values rooted in the culture of the nation which may serve as examples in life and a source of further literary, language, and culture studies. Thus, the results of research on religious values in traditional Seloko of Jambi Malay has a positive contribution in many aspects of life.

Conceptually religious values is closely associated with goodness, even though the the facts is that such goodness may differ from one another (Kattsoff 2004: 318). According to Bakker (1984: 37) religious values, appear in the form of acts of worship, physical health, sensitivity, the intelligence of the mind, and spiritual wealth that makes people become wise. The concept of value in this study cannot be separated from the culture of Jambi Malay society that is implicitly reflected in traditional Seloko of Jambi Malay. Religious values are the values created through religious teachings that have been internalized in a person are is reflected in their day to day attitudes and behavior. Attitudes and good human behavior in relation to God, the surrounding nature, fellow human beings or the society and the relationship with oneself.

\section{METHOD}

This research is based on qualitative approaches with content analysis method. Data were collected from a variety of documents and for the disclosure of religious values in Traditional Seloko, sources from Seloko lines in a collection of texts of Seloko customary law were taken. This research data, namely lines from traditional Seloko of Jambi Malay has been documented by the Indigenous Institute of Jambi. Qualitative data sources may be taken from the result of observation, interviews, personal and official documents, photographs, recordings, pictures, and informal conversations (Emzir, 2010: 37). Source of this research data are in the form of personal and official documents. Primary data is taken from the documents of Indigenous institutions of Jambi Province in the book Pokok-Pokok Adat Jambi Sembilan Lurah: Dasar-Dasar Hukum Ada dan Sastra Adat Jambi (Syam, 2002:1).Secondary data are taken from books of indigenous elders or people who have knowledge of TraditionalSelokoof Jambi Malay.According to (Moleong, 2007: 330) qualitative research instruments refer to researcher as a data collector or qualitative research using research as an instrument. Research procedure is done in three steps: provision of data, data validation, and data inference or analysis. To obtain the validity of data, triangulation techniques namely theoretical and logicaltriangulation were used.

This study uses content analysis of Klaus Krippendorff (2004: 97-99) and hermeneutic interpretation techniques of PaulRicoeur (2002: 35). Both of these methods are used in an integrated manner, as both have similarities in interpreting any text symbols of Seloko of Jambi Malay customary law being interpreted. The mechanism of hermeneutics analysis or interpretation of the traditional text of Jambi Malay Seloko includes six steps: 1) At first the text (Seloko custom) was placed as the object under the study as well as an autonomous subject or center. 2) Furthermore, indigenous Seloko as ontology facts were understood by making the 
structure as an object, here the structural analysis had an important position. Analysis of the structure is intended to obtain religious values in the structure of traditional themes Seloko of Jambi Malay. 3) Understanding is widened when being entered in the symbolization layer.The Understanding of the symbols in the Seloko text has exceeded the limit structure but understanding was still in the text. 4) Interpreting codes based on the notion of symbolic reasoning. Code of symbols in the text being interpreted will of course need referential matters and connection of the same with the symbols outside the text. 5) symbolic code reflected by the text and associated with various problems outside the text requires other disciplines to complete the interpretation. 6) Finally, the end of the process is the discovery of the meaning or message of the text.

\section{RESULT}

Seloko of Jambi Malay Customary law consists of rules of customary laws which governs aspects of personal and social life. Seloko expression of customary law is the unwritten law, but aims to maintain order and security for the communities. Religious values in the theme structure of Seloko customary law are reflected in the text of the basics of Seloko customary law and the laws of customary law, as summarized in the following table.

Table 1. Religious Values in the Theme Structure of Seloko Customary Law

\begin{tabular}{|c|c|}
\hline SHA Text & Meaning \\
\hline $\begin{array}{l}\text { Titian teras bertanggo batu “A terrace with } \\
\text { rock stairs” }\end{array}$ & $\begin{array}{l}\text { Laws originating from Sunnah of Prophet } \\
\text { Mohammad ( Hadist). } \\
\text { Laws originating from God's commandment } \\
\text { (Alquran). }\end{array}$ \\
\hline $\begin{array}{l}\text { Cermin gedang nan tidak kabur. "Big and } \\
\text { clear mirror" }\end{array}$ & $\begin{array}{l}\text { Existing provisions emanating from the past that } \\
\text { proved to be the truth and goodness in protecting } \\
\text { society inherited from generation to generation }\end{array}$ \\
\hline $\begin{array}{l}\text { Lantak nan tidak goyah. "A pile which is } \\
\text { unshakeable” }\end{array}$ & $\begin{array}{l}\text { The legal provisions which have existed for a long } \\
\text { time which if amended would cause chaos, it must } \\
\text { be maintained with all the risks. }\end{array}$ \\
\hline $\begin{array}{l}\text { Tidak lapuk kareno hujan, } \\
\text { Tidak lekang kareno panas.”Not worn by rain, } \\
\text { not torn by heat. }\end{array}$ & Holding on to the unfazed truth \\
\hline Kato seiyo & $\begin{array}{l}\text { Provisions which have been deliberated and } \\
\text { agreed upon. }\end{array}$ \\
\hline
\end{tabular}

Based on the meaning of the Seloko text as referred to above, it can be seen that there are five religious values in the Seloko theme of Jambi Malay customary primary law, namely: 1) The customary law which is characterized by the Qur'an and hadith. 2) Customary law based on truth and goodness. 3) Customary law based on fairness and honesty. 4) Customary law based on obedience to the law. 5) Customary law based on deliberation and consensus.

In the structure of the Seloko theme of customary law religious values which forbid minor or severe crimes were found. Based on the research findings, there are 20 types of prohibition of crimes both individually and in groups revealed in the data in the following table. 
Table 2. Religious Values in Seloko Theme Structure of Customary Law

\begin{tabular}{|c|c|}
\hline SHA Text & Meaning \\
\hline Dago-dagi & Making mistakes and instigate domestic chaos (disturbances) \\
\hline Sumbang salah, & $\begin{array}{l}\text { Matters which, according to public opinion,are deemed unfit / } \\
\text { clearly wrong }\end{array}$ \\
\hline Samun sakai & Robbery with homicide, \\
\hline Upas racun & $\begin{array}{l}\text { Murder by poisoning of the victim and make him/her suffer from } \\
\text { illness or death. }\end{array}$ \\
\hline Siur bakar & The act of deliberately burning homes, villages, and farms \\
\hline Tipu tepok & Harming others by fraud and solicitation. \\
\hline Maling curi & Taking someone else's property without the owner's knowledge \\
\hline Tikam bunuh & Hurting or injuring others to death with a a sharp weapon \\
\hline $\begin{array}{l}\text { Lebam-baluh di tepung } \\
\text { tawar }\end{array}$ & $\begin{array}{l}\text { People who are physically injuring another person which causes scar } \\
\text { shall treat the victim. }\end{array}$ \\
\hline Luka-lukih dipampas & $\begin{array}{l}\text { People who are physically injuring another person shall be obliged } \\
\text { to pay compensation. }\end{array}$ \\
\hline Mati dibangun & The person who kills another person shall pay indemnity (diyat). \\
\hline Samun sakai & Robbery in residential area. \\
\hline $\begin{array}{l}\text { Salah makan diluahkan, } \\
\text { Salah bawa dikembalikan } \\
\text { Salah pakai diluluskan }\end{array}$ & $\begin{array}{l}\text { Any losses incurred person against another person must be } \\
\text { compensated. }\end{array}$ \\
\hline $\begin{array}{l}\text { Hutang kecil dilunasi, } \\
\text { hutang besak diangsurkan }\end{array}$ & $\begin{array}{l}\text { All debts must be paid, if the amount is it must be paid in full and if } \\
\text { the amount is big it must be paid in installments. }\end{array}$ \\
\hline Golok gadai, timbang lalu & $\begin{array}{l}\text { Property being mortgaged or pledged over a loan will become the } \\
\text { right of the collateral holder when it is due. }\end{array}$ \\
\hline $\begin{array}{l}\text { Tegak mengintai lenggang, } \\
\text { duduk mengintai kelam, } \\
\text { tegak duo begandeng duo }\end{array}$ & $\begin{array}{l}\text { A relationship that violates decency between men and women, when } \\
\text { it occurs between unmarried women and men. }\end{array}$ \\
\hline $\begin{array}{l}\text { Memekik mengentam tanah, } \\
\text { menggulung lengan baju, } \\
\text { menyinsing kaki seluar }\end{array}$ & Challenging another person to fight, \\
\hline $\begin{array}{l}\text { Menempuh dan bersawah } \\
\text { manjat nan rebak }\end{array}$ & Entering prohibited places. \\
\hline $\begin{array}{l}\text { Meminang diatas pinang, } \\
\text { menawar di atas tawar }\end{array}$ & $\begin{array}{l}\text { Propose other people's fiancée or bidding on an item that is in } \\
\text { another person's bid }\end{array}$ \\
\hline Umo bekandang siang, & The fields are maintained during the day. \\
\hline ternak bekandang malam & Cattles must be caged at night. \\
\hline Pinjam memulangkan & A person borrowing something shall be require to return it. \\
\hline Hilang mengganti & A person losing something shall replace it. \\
\hline Sumbing menitik & A person damaging something shall repair it \\
\hline
\end{tabular}

Based on these outcome of this study there are eight types of serious crimes which are classified as violations of customary law of Jambi Malay. In the above table the eighth type of crime include: 1) instigating riots, 2) committing obscene behavior, 3) robbing, 4) poisoning, 5) burning, 6) cheating, 7) stealing, and 8) killing. It is a violation of customary law and are conflicted with religious values of Jambi Malay society. Therefore, any kind of violation of the customary law also violates the religious values of Islam which is based on customary law which will be penalized according to the law of Islam.

\section{DISCUSSION}

The theme is the essence or the subject matter of a discussion. Hence the theme of traditional Seloko is the subject matter of religious values contained in the Seloko. 
Based on research findings that have been described earlier, the religious values in SHA revealed that Seloko sets out the customary law and customary law. In detail, religious values are discussed in accordance with the method of content analysis and hermeneutics analysis techniques. Religious values in the structure of the theme of the foundations of customary law will be discussed as follows.

The first theme of Seloko of primary customary law is customary law of Jambi Malay which is characterized by religious law derived from the Qur'an and Hadith. This was revealed at the basics of data of Seloko Jambi Malay customary law which reads: Titian tereh betanggo stone "Bridges with stone patio " Meaning: The Jambi Malay Customary Law is based on the laws of the religion (Islam). Excerpts of Seloko of primary customary law of Jambi Malay contains religious values are included into the dimension of faith. Customary law is based on Qoran and the Hadith which is highest source of law in the Islamic religion which is is divine revelation (the Qur'an) and the Sunnah or Hadith of the prophet. Religious values in the structure of the theme of the foundations of customary law is clarify in a few SHA expressions such as in the quote of the following data.

Adat besendi syarak, Syarak besendi Kitabullah.

Syarak mengato, adat mememakai.

Syarak bebuhul mati, adat berbuhul sentak

"Adat bersendi syarak, Syarak bersendi kitabullah

Syarak mengatakan, adat mememakai

Syarak bebuhul mati, adat berbuhul sentak"

The first line reflect confidence in the customary laws based on religious law that comes from the Book of Allah (Al-Quran). In this case the religious values is related to man's relationship with God. The second line, the phrase Seloko above reflect religious values related dimensions of ideology or compliance to religious rules.Ideology dimensionnamely obedience to the teachings of Islam namely matters which have been regulated and provided in the Qur'an, it must be carried out in customary law / Syarak mengato custom using / "Religion says, custom obey ". While the third line of the Seloko above, contained dimensions of religiosity associated with the implementation of Shari'a religious worship and make religion as a value system that forms the mental attitude or thinking patterns will affect the pattern of behavior as stated in Seloko expression.

Ambek tuah kepado yang menang, ambek teladan kepado yang elok.

"Take notes from the winning, take example from the good"

Baju bajait yang dipakai, jalan berambah yang diturut.

"Sewn clothes are worn, branched roads are taken"

Religious values contained in the structure of the theme Seloko above refers to the implementation of primary customary law relating to the values of justice and fairness. Seloko expression that contains the Jambi Malay customary law based on fairness and firmness expressed in Seloko quote:Lantak nan tidak goyah "An unshakeable pile”. Seloko of the primary customary law implies that in determining the sentence and those who carry it out should have unwavering mental and determination. This expression stated that customary law enforcement should be firm 
and strong without being discriminative and may not be influenced by anyone, as reflected in the followingphrase of Seloko:

Tibo dimata idak dipicingkan, Tibo diperut idak dikempeskan, lurus benar dipegang teguh, kata benar diubah tidak.

"A sight in the eye is not squinted, arrived in the stomach is not inflated, what is straight and true must be held firm, a true words must not be changed"

Religious values contained in the Seloko are the values of justice, honesty, and resolute in upholding the truth. It's close relation to religious values in the relationships between human beings.

Furthermore, the theme of obedience to the law is the meaning contained in the SHA. All laws which came from sources of Islamic law are retained until whenever, wherever and with any risk. This is contained in the symbolic meaning of the text of the following traditional Seloko.

Dak lapuk dek hujan, dak lekang dek panas.

"Not worn by rain, not torn by heat"

The next religious values in the theme of the primary customary law of Jambi Malay law is deliberation and consensus. Katosaiyo. "The word seiya" in the Selokoquote is related to customary law decision-making based on deliberation and consensus. An agreement is obtained through negotiation by listening to as many opinions of people who should be heard as possible so that an agreement will be reached as to which are highlighted in the following expression.

Kato seorang dibulatkan,kato bersama dimupakati.

"A word of a person is agreed upon, the collective words are covenant"

Pipih tidak bersudut boleh dilayangkan, bulat tidak bersanding boleh digulingkan. " Flat with no corner may be flown, round and not edged may be rolled "Bulat air dek pembuluh, Bulat kato dek mupakat. “ Bulat air dek pembuluh,Bulat kato dek mupakat”

Religious Values in theme structure of Seloko customary laws are related to the prohibition of crimes. Based on data findings Seloko customary law there are 20 rules on the prohibition of evil called nan twenty legislation. In detail, the twenty of these rules contain themes related to religious values. The themes of the violation of religious values contained in the Law of Jambi Malay customary law is expressed in the following Seloko:

Dago-dagi, "riots"

Meaning: committing offenses against the government and instigating domestic chaos

The phrase dago-Dagi is traditional selokoin form of a special phrase. The phrase is associated with any action that violates the public interest or the interests of society, causing chaos in the country such as riots, demonstrations anarchy. Riots against government which undermine the public interest is clearly prohibited by the religion.

Sumbang- salah, "sumbang-salah"

Meaning: Deeds which is believed by many as wrong (false) is clearly wrong. 
The expression sumbang-salah, is one of the types of crimes that are often committed by a person or group of people who are opposed to religious norms or in violation of customary law. Therefore, the structure of this Seloko themes related to the forbidden act according to public opinion and deemed unfit like sitting alone in the dark with an unrelated woman. These acts are clearly contrary to religious values.

The following seloko expression is associated with acts such as robbery and murder: Samun-sakai "Samun-sakai"

Robbery with murder and forceful acquisition of property of others. These acts constitute the crime of taking property or the rights of others by force with the persecution and destruction. This is clearly contrary to the rules of religion and violate religious values. / Upas-racun /, "upas-racun". Seloko traditional expression of Jambi Malay is related to the prohibition of murder using poison or upas. People who are exposed upas usually dies instantly while those exposed to poison will suffer a long illness before death. Such actions are contrary to religious values.

Tipu-tepok expression refers to the act a person or group of people to get things that benefit themselves by means of deception and persuasion or false state. Another phrase to describe the crime that is stab-kill, which refers to the act of violence on another person using a sharp weapon or other means so as to cause death. Furthermore, expression of a thief-stealing refers to the act of taking the goods of others with the intent without telling their owners either on day or night time. All such actions are in violation of customary law and contrary to religious values associated with the relationship between human beings.

In Seloko customary law, the crime of beating everyone else to leave physical scars, including violations of customs laws and will be subject to sanctions. Sanctions are customary that the perpetrator is obliged to treat people who were beaten. This was revealed in Seloko: Inert-baluh in fresh flour "Inert-baluh in fresh flour". Sanctions are customary that the perpetrator is obliged to treat those who were injured to recover and to pay a fine or compensation as Seloko phrase that reads: Luka luki dipampas "wounds must be compensated".The implementation of compensation or fines are divided into three groups depending on how the injuries experienced by the victims, namely: 1) low cuts that are not severe injuries or be covered with clothing, the compensation is a chicken, and a bushel of rice and coconut. 2) deep wound that is wound in such a devastating injury, but is not too severe, the compensation is a goat and 20 bushels of rice, 3) severe injuries, the compensation is "bangun". Bangun (equals to diyat) penalties for killing are a buffalo, a hundred bushels of rice and 1 yard of fabric.

Seloko expression is also related to unlawful acts against customary law namely murder. This type of violation of customary law is among the most severe, because it was customary legal sanctions given to people who are breaking too heavy. The expression "mati dibangun", means that if someone kills another person he or she must pay a wake or a fine that is a buffalo, a hundred bushels of rice and 1 yard of fabric. These fines will be handed over to the indigenous leaders of a village or to Batin to be eaten together with the community.

Furthermore Seloko expression of customary law is also relating to crimes of robbery. As was explained earlier that in the environment of Jambi Malay community, crime of robbery could occur in various places, in the wilderness which is called as the Seloko "Samun in gajah dumun", robbery at the forest frontier settlements mentioned by Seloko "Samun seperti dumun", and robberies in the 
settlement area is called "Samun diadundumun". Therefore, to determine the customary sanctions against the perpetrators of the robbery is determined by the state of the victim who was robbed.

The Seloko text of customary law also explains matters related to any actions that harm others. The phrase, "Salah makan diluahkan, salah bawa dikembalikan, salah pakai dilepaskan " implies that any harm caused someone to someone else, shall be compensated by the offender.

There is also Seloko expression which is related to violations of customary law particularly matters of debts. Seloko expression,:/ "Small debt must be paid in full, large debts is paid in installments"/. The symbolic meaning of the phrase is that if someone has a small debt he is required to pay it off, but if the debt is large or big he can pay it off in installments. However, in case of later conflicts due to debt problems will usually be resolved amicably. The same applies to matters related to the mortgaged property. In the customary law, there is Seloko expression that reads: / Golok gadai, timbang lalu/. The symbolic meaning of the phrase / golok gadai/ are mortgaged property or object, whereas the symbolic meaning of the phrase / timbang lalu/ is the rights holders of collateral. Therefore, grammatically this Seloko phrase implies that the mortgaged or pledged property or objects over a debt will automatically becomethe rights of the collateral rights if and when the lender fall to redeem the object mortgaged or pledged.

In the Seloko of customary law a relationship which violates the rules or norms in society is also regulated. This was revealed in Seloko which reads:Tegak mengintai lenggang, duduk mengintai kelam, tagakduobegandengduo, salah bujang dengan gadis, kawin. That phrase refers to how the relationship between a man and a woman. A relationship that violates decency, which occur between married women and other men will be penalized. Religious values which are reflected in this theme is related to the relation between human beings and the society.

A theme of Seloko text in customary law in Jambi Malay society also related to fighting. This is expressed in the following Seloko: The phrase, memekik mengentam tanah, menggulung lengan baju, menyinsing kaki seluar. The symbolic meaning of this Seloko is related to the prohibition against people fighting. People who ignite or incite fights are violating customs laws and may be subject to sanctions. This is in line with the prohibition in Islam and is clearly contrary to religious values.

In Seloko of customary law, entering forbidden areas is included in a violation of customary law. Seloko text which reads: Menempuh nan bersawa, memanjat nan berebat, implies a prohibition to enter certain areas or to do something which is forbidden. It also deals with prohibition to propose other people's fiance, bid on items that are in the bidding of others. In the selokoof the customary law it is stated seloko Meminang diatas pinang, menawar di atas tawar. "Meminang diatas pinang, menawar di atas tawar'. The symbolic meaning of the selokotext is prohibition to woo a girl who was on the other end of marriage proposal of other person. If it is done, it may be subject to customary legal sanctionin form of a goat and 20 twenty bushels of rice. Religious values as reflected in the text of this Seloko associated with man's relation to man and man to nature which included aspects of honorable behavior.

In addition, there is also the theme of Seloko of the customary law related to property maintenance rules namely rice fields and livestock farms. This was 
expressed in a Seloko text quote that reads: Umobe kandang siang, ternak bekandang malam, "Rice field is taken care at daytime, livestock is caged at night", contains the meaning of the obligations in the maintenance of property. The theme contained in the phrase is closely related to religious values in man's relationship with nature.

Research on religious values in the structure of Seloko theme of Jambi Malay customary law, only reveal a fraction of the inner structures of seloko particularly the theme structure. Therefore, whenever possible to gain a broader and more indepth understanding to the religious values in traditional seloko of Jambi Malay, review on structures either mental and physical structure of seloko or the structure of diction, figure of speech, and images must be done.

\section{CONCLUSION}

Religious values are reflected in the structure of the theme of traditional Seloko of Jambi Malay which include: 1) aspect of confidence associated with man's relationship with God, so that the essence of customary law and laws in customary law Jambi Malay are based on Islamic law derived from the Quran and hadiths. 2) Aspects of Good Behavior associated with man's relationship with other man which reflects Islamic values in public life 3) dimension of science science or aspect of knowledge relating to the knowledge of the proper and true religious teachings, 4) dimensions of human relationship which is related to implementation of Islamic values in life associated with the relation between human beings or society as well as relationship of man with nature.

Based on the conclusions as described above, there are three suggestions that need to be addressed, namely: 1) Religious values contained in the structure of the theme of traditional Seloko of Jambi Malay which is based on Islamic law need to be passed on from an early age to the students in order to screen foreign cultures, 2) the religious values of the structures of theme of traditional Seloko of Jambi Malay are symbols of the culture of Jambi Malay society, so it is necessary to keep local culture against assimilation with foreign cultures. 3) The values are loaded with the noble values of humanity so that it can be used as a source of characterslearning.

\section{REFERENCES}

Bakker, J W M. Filsafat Kebudayaan. Yogyakarta: Kanisius, 1984.

Bertens, K. Etika. Jakarta: Gramedia Pustaka Utama, 2011.

Cassirer, Ernst. An Essay on Man. Fredericksburg: Book Crafters, 1979.

Emzir. Metodologi Penelitian Kualitatif Analisis Data. Jakarta: Rajawali Press, 2010.

Kattsoff, O. Louis. Pengantar Filsafat, terjemahan Soejono Soemargo, Yogyakarta: Tiara Wacana, 2004. 
Krippendorff, Klaus. ContentAnalysis: Introductionto its Theory and Methodology, California: SagePublications, Inc, 2004.

Lexy J. Moleong. Metodologi Penelitian Kualitatif. Bandung: Remaja Rosda Karya, 2007

Mayring, Philipp. Qualitative Content Analisis dalam Forum: Qualitative Social Recearch, Vol. 1. Nomor 2 Juni tahun 2000, http://www.qualitative Research.net/fqs-texte/2-00mayring-e-htm 20/8/2003

Mangunwijaya, Y.B., Sastra dan Religiositas. Yogyakarta: Kanisius. 1988.

Ricoeur, Paul, The Interpretation Theory, Filsafat Wacana Membelah Makna dalam Anatomi Bahasa, terjemahan Musnur Hery. Yogyakarta: IRCiSOD, 2002.

Syam, Hasip Kalimudin, Pokok-pokok Adat Pucuk Jambi Sembilan Lurah: Sejarah Adat Jambi. Jambi: LembagaAdat Jambi, 2001.

Sagimun M.D. Adat Istiadat Daerah Jambi. Jakarta: Depdikbud, Proyek Inventarisasi dan Dokumentasi Kebudayaan Daerah, 1985.

Thontowi, Ahmad, Hakekat Religiusitas, https://wwwgoogle.co.id/sumselkemenag. (diakses 3 Maret 2013)., 